\title{
Povidone-Iodine as a Pre-Procedural Mouthwash to Reduce the Salivary Viral Load of SARS-CoV-2: A Systematic Review of Randomized Controlled Trials
}

\author{
Alvaro Garcia-Sanchez ${ }^{1, *} \mathbb{\infty}$, Juan-Francisco Peña-Cardelles ${ }^{2,3,4} \oplus$, Esther Ordonez-Fernandez ${ }^{5}$, \\ María Montero-Alonso ${ }^{6}$, Naresh Kewalramani ${ }^{7}{ }^{(D}$, Angel-Orión Salgado-Peralvo ${ }^{8, *(D)}$, Dániel Végh ${ }^{9,10}{ }^{(D)}$, \\ Angélica Gargano ${ }^{5}$, Gabriela Parra ${ }^{5}$, Lourdes-Isabela Guerra-Guajardo ${ }^{5}$ and Wataru Kozuma ${ }^{4,11}$
}

Citation: Garcia-Sanchez, A.; PeñaCardelles, J.-F.; Ordonez-Fernandez,

E.; Montero-Alonso, M.;

Kewalramani, N.; Salgado-Peralvo, A.-O.; Végh, D.; Gargano, A.; Parra,

G.; Guerra-Guajardo, L.-I.; et al.

Povidone-Iodine as a Pre-Procedural

Mouthwash to Reduce the Salivary

Viral Load of SARS-CoV-2: A

Systematic Review of Randomized

Controlled Trials. Int. J. Environ. Res.

Public Health 2022, 19, 2877.

https://doi.org/10.3390/

ijerph19052877

Academic Editors: Zhengchao Dong, Juan Manuel Gorriz and Yudong Zhang

Received: 26 January 2022

Accepted: 27 February 2022

Published: 1 March 2022

Publisher's Note: MDPI stays neutral with regard to jurisdictional claims in published maps and institutional affiliations.

Copyright: (C) 2022 by the authors Licensee MDPI, Basel, Switzerland. This article is an open access article distributed under the terms and conditions of the Creative Commons Attribution (CC BY) license (https:// creativecommons.org/licenses/by/ $4.0 /)$
1 Department of Oral Health and Diagnostic Sciences, School of Dental Medicine, University of Connecticut Health, Farmington, CT 06030, USA

2 Department of Health Sciences, Rey Juan Carlos University, 28040 Madrid, Spain; juanfranciscopenacardelles@gmail.com

3 Oral and Maxillofacial Surgery Department, School of Dental Medicine, University of Connecticut Health, Farmington, CT 06030, USA

4 Department of Prosthodontics, School of Dental Medicine, University of Connecticut Health, Farmington, CT 06030, USA; w.kouzuma@gmail.com

5 Division of General Dentistry, Department of Craniofacial Sciences, School of Dental Medicine, University of Connecticut Health, Farmington, CT 06030, USA; orfe.esther22@gmail.com (E.O.-F.); angelicatmunoz93@gmail.com (A.G.); drparrabarillas@gmail.com (G.P.); lourdes.iguerrag@gmail.com (L.-I.G.-G.)

6 Pediatric Service, Hospital Álvaro Cunqueiro, 36213 Vigo, Spain; maria.montero.alonso@gmail.com

7 Department of Nursery and Stomatology, Rey Juan Carlos University, 28922 Madrid, Spain; k93.naresh@gmail.com

8 Department of Stomatology, Faculty of Dentistry, University of Seville, 41009 Seville, Spain

9 Department of Prosthodontics, Semmelweis University, 1085 Budapest, Hungary; vegh.daniel.official@gmail.com

10 Division of Oral Surgery and Orthodontics, Department of Dentistry and Oral Health, Medical University of Graz, 8010 Graz, Austria

11 Department of Regenerative and Reconstructive Dental Medicine, Tokyo Medical and Dental University, 1-5-45 Yushima, Bunkyo-ku, Tokyo 113-8549, Japan

* Correspondence: ags.odon@gmail.com (A.G.-S.); orionsalgado@hotmail.com (A.-O.S.-P.)

\begin{abstract}
The use of pre-procedural rinses has been investigated to reduce the number of viral particles and bacteria in aerosols, potentially decreasing the risk of cross-infection from severe acute respiratory syndrome coronavirus 2 (SARS-CoV-2) during medical and dental procedures. This review aims to confirm whether there is evidence in the literature describing a reduction in salivary load of SARS-CoV-2 when povidone-iodine (PVP-I) is used as a pre-intervention mouthwash. An search of the MEDLINE, Embase, SCOPUS, and the Cochrane library databases was conducted. The criteria used followed the PRISMA ${ }^{\circledR}$ Statement guidelines. Randomized controlled trials investigating the reduction of salivary load of SARS-CoV-2 using PVP-I were included. Ultimately, four articles were included that met the established criteria. According to the current evidence, PVP-I is effective against SARS-CoV-2 in saliva and could be implemented as a rinse before interventions to decrease the risk of cross-infection in healthcare settings.
\end{abstract}

Keywords: COVID-19; SARS-CoV-2; mouthwashes; mouthrinse; aerosols; chlorhexidine; povidone-iodine; cetylpiridinium chloride; hydrogen peroxide; colony-forming units

\section{Introduction}

Aerosols are defined as particles of liquid or solid in gas and are $\leq 5 \mu \mathrm{m}$ in diameter [1]. Due to their small size, they are inspirable and can remain suspended in the air for hours [2]. These particles are generated by aerosol-generating procedures (AGPs) in medical settings, 
including airway suctioning, bronchoscopies, and high-flow oxygen therapy, among many others [3]. Subsequently, aerosols in dental offices are generated by the frequent use of high-speed handpieces, ultrasonic devices, and 3-in-1 air-water syringes. For this reason, dentists are one of the collectives that have the highest risk of infection of COVID-19 due to the close proximity with the patients' oral cavities and the numerous AGPs performed routinely [4]. Saliva and blood are main components for viral and bacterial spread; therefore, procedures that generate aerosols should be minimized. However, dental clinicians have a particularly limited range of options regarding treatments and armamentarium that do not generate aerosols [4].

The primary mode of transmission of severe acute respiratory syndrome coronavirus 2 (SARS-CoV-2) is through aerosols and respiratory droplets generated during daily activities, such as speaking or coughing [5]. Several factors, including the immune response of the host, the pathogenicity of the virus, and the amount of infected particles, determine the susceptibility of being infected via an aerosol [6-8]. Furthermore, it has been demonstrated that COVID-19-positive patients present high viral loads in saliva [9,10]; therefore, healthcare professionals performing AGPs have a greater risk of becoming infected with SARS-CoV-2 [11].

For this reason, there have been several investigations attempting to mitigate the negative effects of aerosols during AGPs. Pre-procedural rinses have been explored to reduce the salivary load of different microorganisms and the colony-forming units (CFUs) in aerosols, which could potentially decrease the risk of cross-infection during medical and dental procedures [9,12-15]. One of the most predominant mouthwash solutions studied is povidone-iodine (PVP-I). This molecule is an iodophor globally used due to its broad-spectrum antiseptic properties with a low number of contraindications, including allergy to iodine, thyroid disease, and pregnancy [16]. Several in vitro studies and, more recently, randomized controlled trials (RCTs) using PVP-I as pre-procedural mouthwash have published their results.

Therefore, this study aimed to investigate the effectiveness of PVP-I used as a mouthwash to decrease the salivary viral load of SARS-CoV-2.

\section{Materials and Methods}

\subsection{Protocol}

This review was performed according to the Preferred Reporting Items for Systematic Reviews and Meta-Analyses (PRISMA ${ }^{\circledR}$ ) Statement $[17,18]$. The protocol was registered at the International Prospective Register of Systematic Reviews (PROSPERO) under the registration number CRD42022303756.

\subsection{Focused Question}

A PICO (P, population/patient/problem; I, intervention; C, comparison; O, outcome) question was formulated based on the PRISMA ${ }^{\circledR}$ guidelines:

"In patients diagnosed with COVID-19 (P), does the use of PVP-I mouthwashes (I) compared to not prescribing them $(\mathrm{C})$ reduce the viral load present in saliva $(\mathrm{O})$ ?"

\subsection{Eligibility Criteria}

Prior to the search, inclusion and exclusion criteria were defined:

\subsubsection{Inclusion Criteria}

Included studies were (a) RCTs; (b) studies in which the participants had a reversetranscription polymerase chain reaction (RT-PCR) examination positive for SARS-CoV-2; (c) studies that used PVP-I as a form of intervention; and (d) studies published in English.

\subsubsection{Exclusion Criteria}

Excluded studies were the following: (a) animal studies; (b) experimental laboratory studies; (c) studies whose study base focused on other areas besides the oral cavity and/or 
oropharynx; (d) studies that did not evaluate the reduction of viral load in saliva; (e) nonRCTs; (f) systematic reviews and meta-analyses; (g) literature review studies; (h) case reports; (i) letters to the editor; (j) abstracts or conference papers; (k) comments; and (l) unpublished articles.

\subsection{Information Sources and Search Strategy}

The search was conducted in four different electronic databases: MEDLINE (via PubMed), Embase, SCOPUS, and the Cochrane library database.

The search strategy was carried out by two researchers independently (A.G.-S. and A.-O.S.-P.). The search was not time-restricted and was updated to January 2022. MeSH (Medical Subjects Headings) terms, keywords, and other free terms were used with Boolean operators (OR, AND) to merge searches: ('povidone' OR 'povidone-iodine' OR 'polyvidone iodine' OR iodopovidone' OR 'PVP-I' OR 'iodine') AND ('COVID-19' OR 'SARS-CoV-2’ OR 'SARS'). These keywords were implemented in all databases according to the syntax rules of each database.

\subsection{Study Records}

The results were independently compared by two authors (A.G.-S. and A.-O.S.-P.) to guarantee completeness and removal of duplicates. Next, the title and abstract of the remaining articles were screened individually. Ultimately, full-text papers to be included in this study were selected following the criteria previously described. Disagreements over eligible articles were resolved by including a third author (J.-F.P.-C.) to reach a consensus.

\subsection{Risk of Bias Assessment}

The methodology of eligible studies was evaluated following the Joanna Briggs Institute (JBI) Critical Appraisal Tool [19] by two independent authors (A.G.-S. and A.-O.S.-P.). The studies were categorized as low-quality (0-7 domains) or high-quality assessment (8-13 domains). A third author (J.-F.P.-C) was included to resolve any disagreements between the two authors.

\section{Results}

\subsection{Study Selection}

The search strategy resulted in 630 articles. There were 218 duplicates; therefore, 412 remained. Then, two authors (A.G.-S. and A.-O.S.-P.) independently examined the titles and abstracts and excluded 375 articles that were beyond the scope of this study. Therefore, we obtained 37 possible references. After reading the full text of those 37 papers, 33 were excluded because they investigated areas other than oral cavity saliva and/or oropharyngeal saliva $(n=6)$ or were experimental laboratory studies $(n=9)$, systematic reviews $(n=1)$, literature reviews $(n=2)$, letters to the editor $(n=12)$, and commentaries $(n=3)$. Therefore, four studies were included in our systematic review (Figure 1$)$.

\subsection{Study Characteristics}

All the studies included were RCTs published in 2020 and 2021. There are some discrepancies in the sample size of the different articles (ranging from 36 to 84). Due to the low number of studies available, it was decided that there would not be exclusion criteria set for a minimum of participants. The total number of patients included within the studies was 221. All patients recruited had a positive RT-PCR examination for SARS-CoV-2.

In these studies, rinsing times ranged between $30 \mathrm{~s}$ and $1 \mathrm{~min}$. In the placebo groups, distilled water [20-22] and saline [23] were used. In the test group, several concentrations of PVP-I were used: $0.50 \%$ [21,23], 1\% [22], and 2\% [20]. All saliva samples were evaluated with RT-PCR. Baseline samples were collected immediately before the interventions. The number of saliva samples after interventions varies among the studies. One study collected one sample of saliva after intervention [22], one collected two samples [23], and two collected three samples $[20,21]$. 


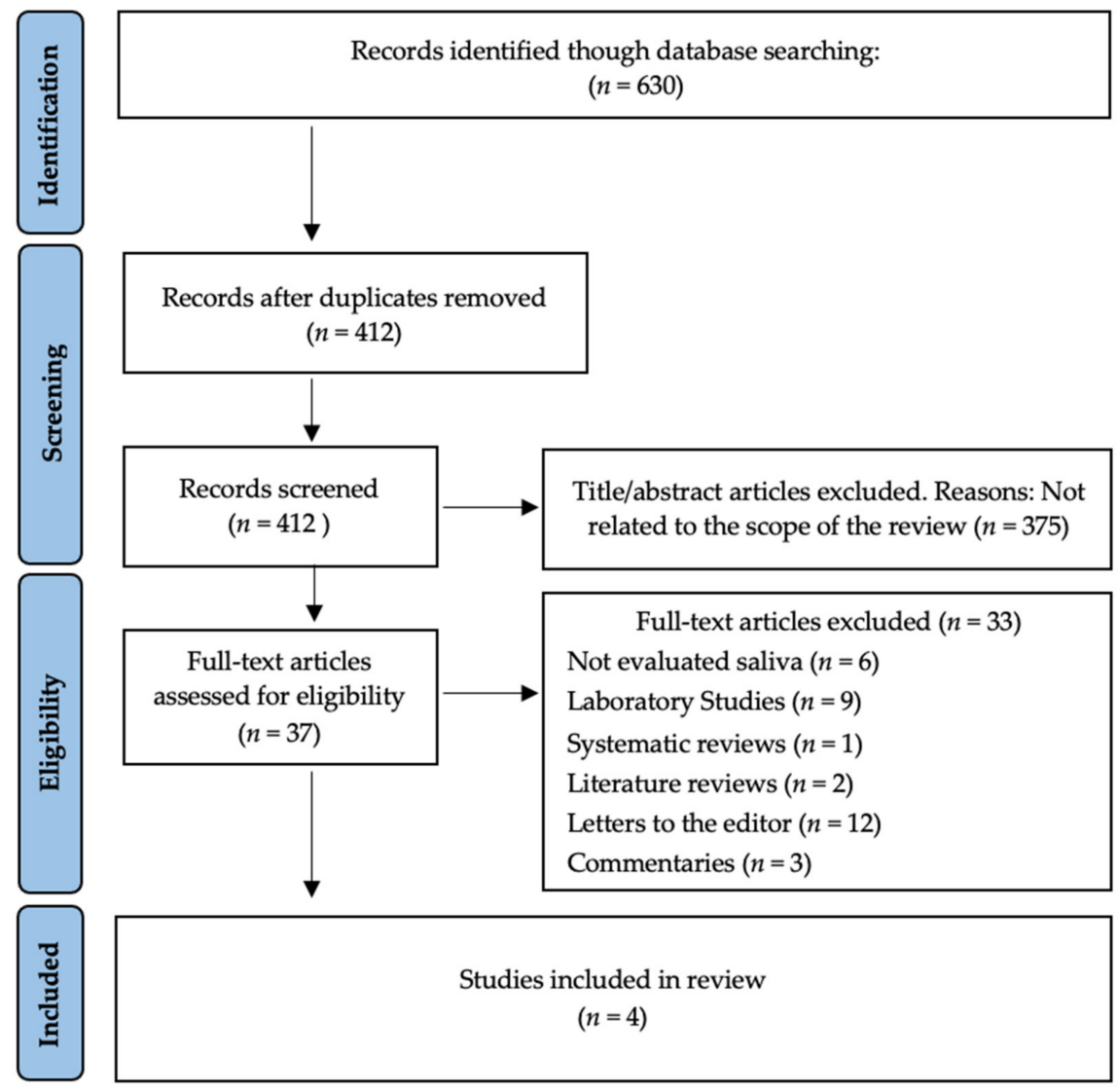

Figure 1. PRISMA ${ }^{\circledR}$ flow diagram of the search processes and results.

A summary of the findings of the included articles is described in Table 1.

Table 1. Results of the included RCTs.

\begin{tabular}{|c|c|c|c|c|c|}
\hline \multirow{2}{*}{ Author/Year } & \multirow{2}{*}{ Sample Size } & \multirow{2}{*}{ Time of Testing } & \multicolumn{2}{|c|}{ Intervention/Duration of Rinses } & \multirow{2}{*}{ Conclusions } \\
\hline & & & Control Group & Test Group(s) & \\
\hline $\begin{array}{l}\text { Chaudhary } \\
\text { et al. [23] } \\
\text { (2021) }\end{array}$ & 40 & $\begin{array}{l}\text { Saliva samples for } \\
\text { RT-PCR }{ }^{1} \text { were } \\
\text { collected at } 15 \text { and } \\
45 \text { min }^{2} \text { post-rinse. }\end{array}$ & $\begin{array}{l}\text { Placebo (normal } \\
\text { saline), } 1 \% / \\
\quad 60 \mathrm{~s}^{3}\end{array}$ & $\begin{array}{c}1 \% \mathrm{HP}^{4}, 0.12 \% \mathrm{CHX}^{5}, 0.50 \% \\
\text { PVP-I }{ }^{6} \text {. Rinsed with } 15 \mathrm{~mL}^{7} / \text { for } \\
60 \mathrm{~s} .\end{array}$ & $\begin{array}{c}\text { All } 4 \text { mouthwashes reduced the } \\
\text { salivary load by } 61 \% \text { through } 89 \% \\
\text { at } 15 \text { min and by } 70 \% \text { through } \\
97 \% \text { at } 45 \mathrm{~min} \text {. }\end{array}$ \\
\hline $\begin{array}{l}\text { Elzein et al. } \\
\text { [22] (2021) }\end{array}$ & 61 & $\begin{array}{c}\text { Saliva was } \\
\text { evaluated with } \\
\text { RT-PCR at baseline } \\
\text { and } 5 \text { min after } \\
\text { rinsing. }\end{array}$ & $\begin{array}{l}\text { Placebo (distilled } \\
\text { water)/ } \\
30 \mathrm{~s} .\end{array}$ & $1 \%$ PVP-I and $0.20 \% \mathrm{CHX} / 30 \mathrm{~s}$. & $\begin{array}{l}\text { The } \mathrm{Ct}^{8} \text { of the intervention } \\
\text { groups (CHX } 0.20 \% \text { and } 1 \% \\
\text { PVP-I) was significantly different } \\
\text { compared to the control group. }\end{array}$ \\
\hline $\begin{array}{l}\text { Ferrer et al. } \\
\text { [20] (2021) }\end{array}$ & 84 & $\begin{array}{l}\text { RT-PCR at baseline, } \\
30,60 \text {, and } 120 \text { min } \\
\text { after mouth rinse }\end{array}$ & $\begin{array}{l}\text { Placebo (distilled } \\
\text { water)/ } \\
1 \text { min. }\end{array}$ & $\begin{array}{c}2 \% \text { PVP-I, } 1 \% \text { HP, } 0.07 \% \text { CPC }^{9}, \\
0.12 \% \text { CHX } / 1 \text { min. }\end{array}$ & $\begin{array}{c}\text { None of the mouthwashes } \\
\text { evaluated presented a statistically } \\
\text { significant change in the salivary } \\
\text { viral load. }\end{array}$ \\
\hline $\begin{array}{l}\text { Seneviratne } \\
\text { et al. [21] } \\
(2020)\end{array}$ & 36 & $\begin{array}{l}\text { Saliva samples for } \\
\text { RT-PCR at baseline } \\
\text { (pre-rinse), } 5 \mathrm{~min}, \\
\text { and } 3 \text { and } 6 \mathrm{~h}{ }^{10} \\
\text { post-rinsing. }\end{array}$ & $\begin{array}{l}\text { Placebo (water)/ } \\
30 \mathrm{~s} \text {. }\end{array}$ & $\begin{array}{c}0.5 \% \text { PVP-I, } 0.20 \% \text { CHX, } 0.075 \% \\
\text { CPC } / 30 \mathrm{~s} .\end{array}$ & $\begin{array}{l}\text { There were no differences in the } \\
\text { reduction of salivary load in all } \\
\text { intervention groups. When } \\
\text { compared with the control group, } \\
\text { PVP-I and CPC showed a } \\
\text { significant decrease at } 6 \mathrm{~h} \text {. CPC } \\
\text { also showed a significant } \\
\text { reduction at } 5 \text { min. }\end{array}$ \\
\hline
\end{tabular}

${ }^{1}$ RT-PCR, reverse-transcription polymerase chain reaction; ${ }^{2}$ min, minutes; ${ }^{3} \mathrm{~s}$, seconds; ${ }^{4} \mathrm{HP}$, hydrogen Peroxide ${ }^{5} \mathrm{CHX}$, chlorhexidine; ${ }^{6} \mathrm{PVP}-\mathrm{I}$, povidone-iodine; ${ }^{7} \mathrm{~mL}$, milliliters; ${ }^{8} \mathrm{Ct}$, cycle threshold; ${ }^{9} \mathrm{CPC}$, cetylpyridinium chloride; ${ }^{10} \mathrm{~h}$, hour(s). 
The central findings of the resulting articles are described as follows:

Chaudhary et al. [23] (2021) evaluated the effect of $0.50 \%$ PVP-I, $1 \%$ hydrogen peroxide (HP), $0.12 \%$ chlorhexidine $(\mathrm{CHX})$, and normal saline. Forty patients were randomly allocated into groups, and saliva samples were collected and tested with RT-PCR. In the PVP-I group, there was a median reduction of $61 \%$ and $97 \%$ at 15 and $45 \mathrm{~min}$, respectively.

Seneviratne et al. [21] (2020) recruited 36 patients that were randomly allocated to four different groups: distilled water (control), $0.50 \%$ PVP-I, $0.20 \% \mathrm{CHX}$, and $0.075 \%$ cetylpyridinium chloride (CPC). Samples were collected before rinsing, $5 \mathrm{~min}$, and 3 and $6 \mathrm{~h}$ post-rinse. Cycle threshold $(\mathrm{Ct})$ changes were estimated at each time-point value. The PVP-I group exhibited greater changes in Ct values after $5 \mathrm{~min}$ and $3 \mathrm{~h}$; however, there was a significant increase in the virucidal activity only at $6 \mathrm{~h}$ when compared to distilled water.

Elzein et al. [22] (2021) performed a triple-blinded RCT evaluating 1\% PVP-I, $0.20 \%$ CHX, and distilled water (control) in 61 patients. Saliva samples were collected at baseline and 5 min post-rinse. The delta $C t$ values $(4.72 \pm 0.89)$ indicated a statistically significant reduction in the salivary viral load after using 1\% PVP-I for $30 \mathrm{~s}$ compared to distilled water $(0.519 \pm 0.519)$.

Ferrer et al. [20] (2021) evaluated the differences in viral load of SARS-CoV-2 in 80 participants using 2\% PVP-I, $1 \% \mathrm{HP}, 0.07 \% \mathrm{CPC}, 0.12 \% \mathrm{CHX}$, and distilled water (control). Samples were collected at baseline, 30, 60, and 120 min post-rinse. There was not a statistically significant reduction in salivary load when $2 \%$ PVP-I was used compared with the control group.

\subsection{Risk Bias Assessment}

Using the JBI Critical Appraisal Tool for RCTs [19], we determined that none of the articles presented a low-quality assessment (0-7 domains), and all of the articles included [20-23] had a high-quality assessment (8-13 domains). Table 2 shows a detailed description of the studies included.

Table 2. JBI Critical Appraisal Tool [19] for RCTs. Reprinted with permission from JBI. Copyright 2020.

\begin{tabular}{|c|c|c|c|c|c|}
\hline & Critical Appraisal Questions & Chaudhary et al. [23] (2021) & Seneviratne et al. [21] (2020) & Elzein et al. [22] (2021) & Ferrer et al. [20] (2021) \\
\hline 1. & $\begin{array}{l}\text { Was true randomization used for the } \\
\text { assignment of participants to } \\
\text { treatment groups? }\end{array}$ & & & & \\
\hline 2. & $\begin{array}{l}\text { Was allocation to treatment } \\
\text { groups concealed }\end{array}$ & & & & \\
\hline 3. & $\begin{array}{l}\text { Were treatment groups similar at } \\
\text { the baseline? }\end{array}$ & & & & \\
\hline 4. & $\begin{array}{l}\text { Were participants blind to } \\
\text { treatment assignment? }\end{array}$ & & ? & & \\
\hline 5. & $\begin{array}{l}\text { Were those delivering treatment blind } \\
\text { to treatment assignment? }\end{array}$ & & $?$ & & \\
\hline 6. & $\begin{array}{l}\text { Were outcome assessors blind to } \\
\text { treatment assignment? }\end{array}$ & & ? & & \\
\hline 7. & $\begin{array}{l}\text { Were treatment groups treated } \\
\text { identically other than the intervention } \\
\text { of interest? }\end{array}$ & & & & + \\
\hline 8. & $\begin{array}{l}\text { Was follow up complete and if not, } \\
\text { were differences between groups in } \\
\text { terms of their follow-up adequately } \\
\text { described and analyzed? }\end{array}$ & & & & \\
\hline 9. & $\begin{array}{l}\text { Were participants analyzed in the } \\
\text { groups to which they } \\
\text { were randomized? }\end{array}$ & ? & ? & ? & ? \\
\hline 10. & $\begin{array}{l}\text { Were outcomes measured in the same } \\
\text { way for treatment groups? }\end{array}$ & & & & \\
\hline
\end{tabular}


Table 2. Cont.

\begin{tabular}{llll}
\hline Critical Appraisal Questions & Chaudhary et al. [23] (2021) & Seneviratne et al. [21] (2020) & Elzein et al. [22] (2021) \\
\hline 11. Ferrer et al. [20] (2021) \\
\hline $\begin{array}{l}\text { Were outcomes measured in a } \\
\text { reliable way? }\end{array}$
\end{tabular}

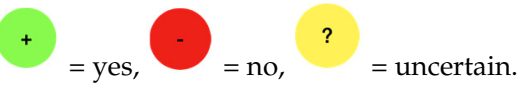

\section{Discussion}

The surface of SARS-CoV-2 presents a spike protein (S) involved in the receptor recognition and cell membrane fusion process. The $S$ protein mediates cell entry when it contacts the angiotensin-converting enzyme 2 (ACE2) receptors [24], and oral mucosa and salivary gland epithelium present a great amount of these receptors [25-27]. In a study by Huang et al. [28], RNA molecules of SARS-CoV-2 were consistently found in ACE2-expressing ducts of salivary glands and in epithelial cells of the oral mucosa. They also proposed that the virus replicating in infected glands and the shedding of the infected oral mucosa are the sources of SARS-CoV-2 in saliva [28].

Patients undergoing medical and dental procedures were thoroughly screened for COVID-19 signs and symptoms as a means to prevent the risk of infection of healthcare providers. However, SARS-CoV-2 mRNA was detected in saliva of asymptomatic/presymptomatic patients [28]. For that reason, it might be beneficial to use mouthwashes, such as PVP-I, to decrease the risk of cross-infection in healthcare settings where AGPs are performed in both confirmed COVID-19 and asymptomatic patients.

PVP-I efficacy in reducing the salivary viral load was compared to other solutions in the articles included in this review. Chaudhary et al. [23] found that reduction in viral load at 15 and $45 \mathrm{~min}$ did not differ among 1\% HP, 0.12\% CHX, and 0.50\% PVP-I. Similarly, Elzein et al. [22] did not find any significant difference in the reduction of salivary load between $0.20 \%$ CHX and 1\% PVP-I, and both were significantly effective compared to distilled water. In the RCT by Seneviratne et al. [21], salivary Ct values within all groups at the different time periods did not demonstrate any significant differences. Nonetheless, compared to distilled water, CPC was significantly more effective at $5 \mathrm{~min}$ and $6 \mathrm{~h}$, while PVP-I was only significantly more effective at the 6-h mark. Ferrer et al. [20] found no statistically significant changes in salivary load of SARS-CoV-2 in any of the mouthwashes evaluated. However, comparing the loads at baseline and after intervention, PVP-I and CPC groups showed mean reductions of $30 \%$, with the highest activity $2 \mathrm{~h}$ after intervention. None of the articles included showed any complications after oral PVP-I use at different concentrations.

Various in vitro studies have also assessed the virucidal activity of PVP-I. Many studies used the logarithmic reductions scales of viral load in their results. As a reference, a $3 \log _{10}$ reduction equals a $99.90 \%$ reduction, and a $4 \log _{10}$ reduction equals a $99.99 \%$ reduction in viral load. Xu et al. [29] found a virucidal activity of $>3 \log _{10}$ with a contact time of $30 \mathrm{~min}$. Hassandarvish et al. [30] evaluated the reduction in salivary viral load using PVP-I at concentrations of $1 \%$ and $0.50 \%$, which resulted in virucidal activities of $>5 \log _{10}(>99.99 \%)$ at 15 and $30 \mathrm{~s}$, respectively. Similar studies found virucidal activities of $>4 \log _{10}$ at 15 [31], 30 [32], and $60 \mathrm{~s}[33,34]$.

When evaluating PVP-I as a nasal rinse, Frank et al. [35] showed a complete inactivation of the virus using $0.50 \%$ PVP-I with a contact time of $15 \mathrm{~s}$. Furthermore, a RCT study by Guenezan et al. [14] evaluated the reductions of viral titers in the nasopharynx using a $1 \%$ PVP-I rinse followed by 1\% PVP-I nasal spray and an application of a 10\% PVP-I balm over nasal mucosa during 7 days. The mean reductions in salivary load were $75 \%$ at day 1 
compared with a reduction of $32 \%$ in the placebo group. However, there was no difference in the reduction of viral load over 7 days.

The results of this systematic review show that PVP-I is a potentially effective preprocedural mouthwash to decrease the salivary viral load of symptomatic and asymptomatic COVID-19-positive patients. The prevention of the asymptomatic transmission of SARS-CoV-2 is still one of the biggest challenges [36], and the implementation of protocols to reduce the salivary load of SARS-CoV-2 before AGPs could play a significant role in decreasing the risk of cross-infection in healthcare settings.

\subsection{Strengths and Limitations}

This systematic review presents several strengths, including an unrestricted search in the literature, the search protocol, data retrieval, and risk assessment analysis performed in duplicate.

However, COVID-19 is a disease that is continuously being investigated, and multiple RCTs are evaluating the use of different mouthwashes in progress at this moment. In addition, this systematic review only included four RCTs; therefore, our results must be interpreted with caution, and further investigations must be carried out soon.

\subsection{Recommendations for Further Research}

This study systematically reviewed the first RCTs investigating PVP-I as a pre-procedural rinse. Further in vitro studies evaluating potential new mouthwash solutions and additional RCTs are needed to demonstrate the safety and efficacy of different mouthwashes.

\section{Conclusions}

Within the limitations of this study, PVP-I presents a significant virucidal activity against SARS-CoV-2 in saliva with concentrations ranging from $0.5 \%$ to $1 \%$. On the other hand, concentrations of $2 \%$ did not show statistically significant changes in salivary load in one of the included studies. In clinical practice, a 30- or 60-s pre-procedural rinse of $0.50 / 1 \%$ PVP-I could be beneficial to reduce the risk of cross-infection in healthcare settings performing AGPs in diagnosed, suspected, or asymptomatic COVID-19-positive patients. However, these results should be taken with caution, as this review included a low number of studies, and additional RCTs are essential to confirm the validity of these findings.

Author Contributions: Conceptualization, A.G.-S. and A.-O.S.-P.; methodology, A.-O.S.-P.; validation, J.-F.P.-C., D.V. and N.K.; formal analysis, A.G.-S. and W.K.; investigation, D.V. and G.P.; resources, E.O.-F.; data curation, A.G. and L.-I.G.-G.; writing—original draft preparation, A.G.-S. and J.-F.P.-C.; writing-review and editing, E.O.-F. and M.M.-A.; visualization, E.O.-F.; supervision, A.-O.S.-P.; project administration, A.G.-S. All authors have read and agreed to the published version of the manuscript.

Funding: This research received no external funding.

Institutional Review Board Statement: Not applicable.

Informed Consent Statement: Not applicable.

Conflicts of Interest: The authors declare no conflict of interest.

\section{References}

1. Tellier, R. Aerosol Transmission of Influenza A Virus: A Review of New Studies. J. R. Soc. Interface 2009, 6, 783-790. [CrossRef] [PubMed]

2. $\quad$ van Doremalen, N.; Bushmaker, T.; Morris, D.H.; Holbrook, M.G.; Gamble, A.; Williamson, B.N.; Tamin, A.; Harcourt, J.L.; Thornburg, N.J.; Gerber, S.I.; et al. Aerosol and Surface Stability of SARS-CoV-2 as Compared with SARS-CoV-1. N. Engl. J. Med. 2020, 382, 1564-1567. [CrossRef] [PubMed]

3. Jackson, T.; Deibert, D.; Wyatt, G.; Durand-Moreau, Q.; Adisesh, A.; Khunti, K.; Khunti, S.; Smith, S.; Chan, X.H.S.; Ross, L.; et al Classification of Aerosol-Generating Procedures: A Rapid Systematic Review. BMJ Open Respir. Res. 2020, 7, e000730. [CrossRef] [PubMed]

4. $\quad$ Li, R.W.K.; Leung, K.W.C.; Sun, F.C.S.; Samaranayake, L.P. Severe Acute Respiratory Syndrome (SARS) and the GDP. Part II: Implications for GDPs. Br. Dent. J. 2004, 197, 130-134. [CrossRef] [PubMed] 
5. Zhou, L.; Ayeh, S.K.; Chidambaram, V.; Karakousis, P.C. Modes of Transmission of SARS-CoV-2 and Evidence for Preventive Behavioral Interventions. BMC Infect. Dis. 2021, 21, 496. [CrossRef]

6. Xu, H.; Zhong, L.; Deng, J.; Peng, J.; Dan, H.; Zeng, X.; Li, T.; Chen, Q. High Expression of ACE2 Receptor of 2019-NCoV on the Epithelial Cells of Oral Mucosa. Int. J. Oral Sci. 2020, 12, 8. [CrossRef]

7. $\quad$ Bennett, A.M.; Fulford, M.R.; Walker, J.T.; Bradshaw, D.J.; Martin, M.V.; Marsh, P.D. Microbial Aerosols in General Dental Practice. Br. Dent. J. 2000, 189, 664-667. [CrossRef]

8. Liu, Y.; Ning, Z.; Chen, Y.; Guo, M.; Liu, Y.; Gali, N.K.; Sun, L.; Duan, Y.; Cai, J.; Westerdahl, D.; et al. Aerodynamic Analysis of SARS-CoV-2 in Two Wuhan Hospitals. Nature 2020, 582, 557-560. [CrossRef]

9. Vergara-Buenaventura, A.; Castro-Ruiz, C. Use of Mouthwashes against COVID-19 in Dentistry. Br. J. Oral Maxillofac. Surg. 2020, 58, 924-927. [CrossRef]

10. To, K.K.-W.; Tsang, O.T.-Y.; Leung, W.-S.; Tam, A.R.; Wu, T.-C.; Lung, D.C.; Yip, C.C.-Y.; Cai, J.-P.; Chan, J.M.-C.; Chik, T.S.-H.; et al Temporal Profiles of Viral Load in Posterior Oropharyngeal Saliva Samples and Serum Antibody Responses during Infection by SARS-CoV-2: An Observational Cohort Study. Lancet Infect. Dis. 2020, 20, 565-574. [CrossRef]

11. Van der Valk, J.P.M.; in 't Veen, J.C.C.M. SARS-Cov-2: The Relevance and Prevention of Aerosol Transmission. J. Occup. Environ. Med. 2021, 63, e395-e401. [CrossRef] [PubMed]

12. Carrouel, F.; Conte, M.P.; Fisher, J.; Gonçalves, L.S.; Dussart, C.; Llodra, J.C.; Bourgeois, D. COVID-19: A Recommendation to Examine the Effect of Mouthrinses with $\beta$-Cyclodextrin Combined with Citrox in Preventing Infection and Progression. J. Clin. Med. 2020, 9, 1126. [CrossRef] [PubMed]

13. Marui, V.C.; Souto, M.L.S.; Rovai, E.S.; Romito, G.A.; Chambrone, L.; Pannuti, C.M. Efficacy of Preprocedural Mouthrinses in the Reduction of Microorganisms in Aerosol. J. Am. Dent. Assoc. 2019, 150, 1015-1026.e1. [CrossRef] [PubMed]

14. Guenezan, J.; Garcia, M.; Strasters, D.; Jousselin, C.; Lévêque, N.; Frasca, D.; Mimoz, O. Povidone Iodine Mouthwash, Gargle, and Nasal Spray to Reduce Nasopharyngeal Viral Load in Patients With COVID-19. JAMA Otolaryngol.-Head Neck Surg. 2021, 147, 400. [CrossRef]

15. Rodríguez-Casanovas, H.J.; de la Rosa, M.; Bello-Lemus, Y.; Rasperini, G.; Acosta-Hoyos, A.J. Virucidal Activity of Different Mouthwashes Using a Novel Biochemical Assay. Healthcare 2021, 10, 63. [CrossRef]

16. Chen, S.; Chen, J.W.; Guo, B.; Xu, C.C. Preoperative Antisepsis with Chlorhexidine Versus Povidone-Iodine for the Prevention of Surgical Site Infection: A Systematic Review and Meta-Analysis. World J. Surg. 2020, 44, 1412-1424. [CrossRef]

17. Moher, D.; Liberati, A.; Tetzlaff, J.; Altman, D.G. Preferred Reporting Items for Systematic Reviews and Meta-Analyses: The PRISMA Statement. PLoS Med. 2009, 6, e1000097. [CrossRef]

18. Moher, D.; Shamseer, L.; Clarke, M.; Ghersi, D.; Liberati, A.; Petticrew, M.; Shekelle, P.; Stewart, L.A. Preferred Reporting Items for Systematic Review and Meta-Analysis Protocols (PRISMA-P) 2015 Statement. Syst. Rev. 2015, 4, 1. [CrossRef]

19. The Joanna Briggs Institute Checklist for Randomized Controlled Trials. Available online: http://joannabriggs.org/research/ critical-appraisal-tools.html (accessed on 3 January 2022).

20. Ferrer, M.D.; Barrueco, Á.S.; Martinez-Beneyto, Y.; Mateos-Moreno, M.V.; Ausina-Márquez, V.; García-Vázquez, E.; Puche-Torres, M.; Giner, M.J.F.; González, A.C.; Coello, J.M.S.; et al. Clinical Evaluation of Antiseptic Mouth Rinses to Reduce Salivary Load of SARS-CoV-2. Sci. Rep. 2021, 11, 24392. [CrossRef]

21. Seneviratne, C.J.; Balan, P.; Ko, K.K.K.; Udawatte, N.S.; Lai, D.; Ng, D.H.L.; Venkatachalam, I.; Lim, K.S.; Ling, M.L.; Oon, L.; et al Efficacy of Commercial Mouth-Rinses on SARS-CoV-2 Viral Load in Saliva: Randomized Control Trial in Singapore. Infection 2021, 49, 305-311. [CrossRef]

22. Elzein, R.; Abdel-Sater, F.; Fakhreddine, S.; Hanna, P.A.; Feghali, R.; Hamad, H.; Ayoub, F. In Vivo Evaluation of the Virucidal Efficacy of Chlorhexidine and Povidone-Iodine Mouthwashes against Salivary SARS-CoV-2. A Randomized-Controlled Clinical Trial. J. Evid.-Based Dent. Pract. 2021, 21, 101584. [CrossRef] [PubMed]

23. Chaudhary, P.; Melkonyan, A.; Meethil, A.; Saraswat, S.; Hall, D.L.; Cottle, J.; Wenzel, M.; Ayouty, N.; Bense, S.; Casanova, F.; et al Estimating Salivary Carriage of Severe Acute Respiratory Syndrome Coronavirus 2 in Nonsymptomatic People and Efficacy of Mouthrinse in Reducing Viral Load: A Randomized Controlled Trial. J. Am. Dent. Assoc. 2021, 152, 903-908. [CrossRef] [PubMed]

24. Letko, M.; Marzi, A.; Munster, V. Functional Assessment of Cell Entry and Receptor Usage for SARS-CoV-2 and Other Lineage B Betacoronaviruses. Nat. Microbiol. 2020, 5, 562-569. [CrossRef]

25. Carrouel, F.; Gonçalves, L.S.; Conte, M.P.; Campus, G.; Fisher, J.; Fraticelli, L.; Gadea-Deschamps, E.; Ottolenghi, L.; Bourgeois, D Antiviral Activity of Reagents in Mouth Rinses against SARS-CoV-2. J. Dent. Res. 2021, 100, 124-132. [CrossRef]

26. Cavalcante-Leão, B.L.; de Araujo, C.; Basso, I.; Schroder, A.; Guariza-Filho, O.; Ravazzi, G.; Gonçalves, F.; Zeigelboim, B.; Santos, R.; Stechman-Neto, J. Is There Scientific Evidence of the Mouthwashes Effectiveness in Reducing Viral Load in Covid-19? A Systematic Review. J. Clin. Exp. Dent. 2021, 13, e179-e189. [CrossRef]

27. Trougakos, I.P.; Stamatelopoulos, K.; Terpos, E.; Tsitsilonis, O.E.; Aivalioti, E.; Paraskevis, D.; Kastritis, E.; Pavlakis, G.N.; Dimopoulos, M.A. Insights to SARS-CoV-2 Life Cycle, Pathophysiology, and Rationalized Treatments That Target COVID-19 Clinical Complications. J. Biomed. Sci. 2021, 28, 9. [CrossRef]

28. Huang, N.; Pérez, P.; Kato, T.; Mikami, Y.; Okuda, K.; Gilmore, R.C.; Conde, C.D.; Gasmi, B.; Stein, S.; Beach, M.; et al. SARS-CoV-2 Infection of the Oral Cavity and Saliva. Nat. Med. 2021, 27, 892-903. [CrossRef]

29. Xu, C.; Wang, A.; Hoskin, E.R.; Cugini, C.; Markowitz, K.; Chang, T.L.; Fine, D.H. Differential Effects of Antiseptic Mouth Rinses on SARS-CoV-2 Infectivity In Vitro. Pathogens 2021, 10, 272. [CrossRef] [PubMed] 
30. Hassandarvish, P.; Tiong, V.; Mohamed, N.A.; Arumugam, H.; Ananthanarayanan, A.; Qasuri, M.; Hadjiat, Y.; Abubakar, S. In Vitro Virucidal Activity of Povidone Iodine Gargle and Mouthwash against SARS-CoV-2: Implications for Dental Practice. Br. Dent. J. 2020. [CrossRef]

31. Bidra, A.S.; Pelletier, J.S.; Westover, J.B.; Frank, S.; Brown, S.M.; Tessema, B. Comparison of In Vitro Inactivation of SARS CoV-2 with Hydrogen Peroxide and Povidone-Iodine Oral Antiseptic Rinses. J. Prosthodont. 2020, 29, 599-603. [CrossRef] [PubMed]

32. Anderson, D.E.; Sivalingam, V.; Kang, A.E.Z.; Ananthanarayanan, A.; Arumugam, H.; Jenkins, T.M.; Hadjiat, Y.; Eggers, M. Povidone-Iodine Demonstrates Rapid In Vitro Virucidal Activity Against SARS-CoV-2, The Virus Causing COVID-19 Disease. Infect. Dis. Ther. 2020, 9, 669-675. [CrossRef] [PubMed]

33. Pelletier, J.S.; Tessema, B.; Frank, S.; Westover, J.B.; Brown, S.M.; Capriotti, J.A. Efficacy of Povidone-Iodine Nasal and Oral Antiseptic Preparations Against Severe Acute Respiratory Syndrome-Coronavirus 2 (SARS-CoV-2). Ear Nose Throat J. 2021, 100, 192S-196S. [CrossRef] [PubMed]

34. Jain, A.; Grover, V.; Singh, C.; Sharma, A.; Das, D.K.; Singh, P.; Thakur, K.G.; Ringe, R.P. Chlorhexidine: An Effective Anticovid Mouth Rinse. J. Indian Soc. Periodontol. 2021, 25, 86-88. [CrossRef] [PubMed]

35. Frank, S.; Brown, S.M.; Capriotti, J.A.; Westover, J.B.; Pelletier, J.S.; Tessema, B. In Vitro Efficacy of a Povidone-Iodine Nasal Antiseptic for Rapid Inactivation of SARS-CoV-2. JAMA Otolaryngol.-Head Neck Surg. 2020, 146, 1054. [CrossRef] [PubMed]

36. Gandhi, M.; Yokoe, D.S.; Havlir, D.V. Asymptomatic Transmission, the Achilles' Heel of Current Strategies to Control Covid-19. N. Engl. J. Med. 2020, 382, 2158-2160. [CrossRef] [PubMed] 